\title{
UNEMPLOYMENT AND SUBSIDIZED UNEMPLOYMENT IN THE WIDER AREA OF AGRINIO IN WESTERN GREECE
}

\author{
Vassilios Mitsos, Gregory Beligiannis and Evaggelos Mosxolouris \\ Department of Business Administration of Food and Agricultural Enterprises, University of Patras Greece \\ DOI: 10.46609/IJSSER.2021.v06i06.001 URL: https://doi.org/10.46609/IJSSER.2021.v06i06.001
}

\begin{abstract}
This paper analyses the problems of unemployment and subsidized unemployment within Western Greece and particularly in Agrinio. Agrinio is one of the largest cities of Western Greece. Unemployment is a crucial problem for the economy of any country, and it is widely accepted that it is associated with a series of negative health consequences, both physical and psychological. Unemployment is also associated with unhappiness, isolation, stress, anxiety and obesity. It threatens democracy, welfare and wellbeing of citizens. Moreover, it creates social inequalities and offends individuals and the state. The purpose of this paper is to study the phenomenon of unemployment in the wider area of Agrinio. Agrinio is one of the biggest cities in Western Greece and it is characterized by several particularities. It is an agricultural area, having no tourism and difficulty in access due to bad road network and no train or airline transport availability. The findings show that youth unemployment is higher. Moreover, unemployment is higher in people with low qualifications. Furthermore, unemployment in Greece has increased after 2009 because of the economic crisis. Last but not least, seasonal subsidized unemployed in Agrinio reduced in summer because most of them are employed in tourism enterprises. Data analysis shows that the most significant factors influencing unemployment in the considered area are the educational level of labor force, the seasonality of works and the economic crisis.
\end{abstract}

Keywords: unemployment, subsidized unemployment, common unemployed person, seasonal work

\section{Introduction}

Nowadays, economic crisis and unemployment damage our society. Both of them are social danger and the most serious problem for the structure and operation of our society. Today, weare experiencing to a great extent the effects of the crisis that hurts private, family and social live of individuals. It leads many citizens to unemployment, to occasional employment or 


\section{International Journal of Social Science and Economic Research}

ISSN: $2455-8834$

Volume:06, Issue:06 "June 2021"

underemployment. Insecurity at work causes mental disorders, melancholy and depression to people. Psychosomatic illnesses due to malnutrition and in inappropriate living and hygiene conditions are called. The person feels disadvantaged and responsible for their condition. At community level, the combination of underemployment with inflation leads to impoverishment of the entire population. Lack of income marginalizes people and exacerbates inequalities and injustices. Governments frequently take measures to reduce unemployment.

\section{Literature Review}

In literature, several researchers cope with this severe problem and its main influencing factors. Various empirical studies engage with the unemployment in several regions of the world. We present some relevant studies in chronological order, from 1988 until today. Firstly, we present four studies from 1988 to 2000: To begin with, Hammarstorm, Janlert and Theorell (1988) conduct their research on a sample of 1083 pupils who attended the last year of compulsory school in a municipality in the northern part of Sweden. The results of the study are the following: unemployment leads to increased psychosomatic and psychological symptoms, decreased social activities in clubs, increased abuse of alcohol and narcotics and increased utilization of health care services. O'Higgins and Niall (1997) present the youth unemployment problem and youth employment policy for a much broader range of countries. As far as the causes of youth unemployment is concerned, it is stated that the basic cause of youth unemployment is insufficient aggregate demand. Moreover, numerous factors influence the effectiveness of youth employment policy. In particular, it is also presented that precise targeting of programs and the involvement of employers' and workers' organizations are both important determinants of an effective policy against youth unemployment. Taylor and Bradley (1997) investigate regional disparities in unemployment in three members of the EU. They attempt to identify the factors responsible for the regional unemployment disparities in Germany, Italy, and the United Kingdom during 1984-94. It is found that a substantial proportion of the variation in unemployment rates between regions can be explained in three key variables: labor costs, industry mix, and employment density. Shimer (1999) in his study states that the U.S. unemployment rate is much lower because the population is much older. This paper argues that the unemployment rate increases from 1957 to 1979 and fall in the subsequent two decades. An increase in education is not translated into a reduction of unemployment. Full-employment rate was so high because of the turnover that is inevitable in a dynamic economy. Secondly, we mention four studies from 2001 to 2010: Lawer, Katsouli and Pallis (2003) in their study estimate changes in cyclical unemployment and output in the EU. They find out that the introduction of the agricultural labor force, in the determination of cyclical unemployment and output, is very important. As a result, the application of "commonagricultural policies" across the 15 EU member states may be questionable because of the different expected effects of these 


\section{International Journal of Social Science and Economic Research}

ISSN: $2455-8834$

Volume:06, Issue:06 "June 2021"

policies on the various economies. Furthermore, Mroz and Savage (2006) investigate the longterm effects of youth unemployment by using National Longitudinal Survey of youth data. They find out the negative effect of unemployment on profitability to be major. Finally, unemployment experienced ten years ago continues to affect earnings adversely. Stephen, Jones and Craig (2006) in their research paper find that marginalattachment - defined as desiring work, is a distinct labor market state, lying between those whodo not desire work and those who are indeed unemployed. Next, Mukoyama and Sahin (2009)in their study present that there has been a substantial increase in the average duration of unemployment relative to the unemployment rate in the U.S. over the last 30 years. They evaluate the performance of a standard job-search model and examine whether the increase within-group wage inequality as also the decline in the incidence of unemployment are capable of accounting the increase in unemployment duration. The results indicate that these two changes can explain a significant part of the increase over the last 30 years. Lastly, we quote five more recent studies from 2010 until today: Dietrich (2013) in his study examines the development of youth unemployment in the period 2001-2010. He claims that the ratio of youthunemployment to the corresponding adult rate was found to have increased in the 2000s until 2008. Finally, Zeilstra and Elhorst (2014) analyze regional and national unemployment differentials in the EU. They investigate the causes of variation in regional unemployment rates from a cross- country perspective. Using annual data pertaining to 142 regions across ten EU countries during 1983-1997, they found that regional and national variables are almost equally important, and that unemployment cannot be addressed with a common policy. Next, Caliendoand Schmidl (2015) occupy with youth unemployment and active labor market policies in Europe. They conclude that since the economic crisis in 2008, European youth unemploymentrates have been persistently high at around $20 \%$ on average. Furthermore, most European countries spend significant resources each year on active labor market programs (ALMP) with the aim of improving the integration prospects of struggling youths. Among the most common programs used are training courses, job search assistance and monitoring, subsidized employment, and public work programs. Putun, Karatas and Akyildiz (2017) in their research paper discover that unemployment has risen to alarmingly high levels in the EU. Moreover, the recent crisis and accompanying lower economic performance has aggravated the condition of youth unemployment. As it is suggested by the results, youth unemployment rate in EU is twiceas higher than average rate of unemployment in the EU. Finally, the impact of youth unemployment is much more serious in Southern members of the EU than that in Northern members. Barslund and Gros (2017) examine European Union (EU) and find out that youth unemployment peaked at 23.5 percent in 2013. Until then, youth unemployment rates had decreased along with economic growth in almost every country across the Union. On average, youth unemployment has fallen by 5 percentage points so that it now stands at 18.8 percent. The rest of the paper is as follows: Firstly, we describe the unemployment in Greece, WesternGreece 


\section{International Journal of Social Science and Economic Research}

ISSN: $2455-8834$

Volume:06, Issue:06 "June 2021"

and Agrinio. Secondly, we discuss the reasons and consequences of unemployment. Then, we describe the methodology. Next, we analyse and present the main findings concerning the sample. Subsequently, we summarize conclusions produced by current research and propose relative measures.

\section{Unemployment in Greece}

The crisis of 2009 hit Greece harder than the rest countries of the EU due to the lack of clear operation rules, mentality and culture of the Greeks, corruption, underground paths of political and economic factors, financial scandals and non-enforcement of laws. In previous years, unemployment in Greece was slightly higher than in European countries. The way the Greek economy operates with small mainly family businesses and on the other hand the support of the family to the members formed a situation with positive results. The economic crisis that began in America in 2008, spreading to other countries and in Greece appeared in 2009 with the first obviously adverse results in 2010. Since then, an increase in unemployment and a decrease in employment until 2013 begins. Since then stabilized in 2015 and begin the first signs of downturn in unemployment. In the last two years, although unemployment in the country fell from $23.3 \%$ in 2016 to $20.9 \%$ at the end of 2017 , it remains very high and remains higher in the EU.

\section{Unemployment in Western Greece}

Unemployment in Western Greece is one of the highest in Greece. Western Greece includes the regions of Achaia, Ilia, Aitoloakarnania, Laconia, Messinia, Fokida, Korinthia, Arcadia, Argolida, Zakynthos and Kefalonia. These areas are experiencing the highest unemployment rates. Exceptions are the islands of Kefalonia-Zakynthos in which employment is particularly high due to tourism and zero unemployment in the tourist season from May to October. Many factories have closed, for example Peiraiki-Patraiki, a company that employed thousands of employees in previous decades. The primary and secondary productive sectors have been abandoned due to general political perceptions. Employment is based mainly on tourism, which although not developed can' $t$ alone cover the offered job. Unemployment in the city of Patras is very high as in most urban centers. Happiness is her port that gives some energy to economiclife. Other supporting factors are the University of Patras with approximately 200,000 studentsand the university hospital that receives patients from all over the Greece.

\section{Unemployment in Agrinio}

When we say wider area of Agrinio we mean the areas belonging to the employment promotion center of Agrinio. It includes the municipality of Thermo, the whole area around Lake Trixonida 


\section{International Journal of Social Science and Economic Research}

(Makrineia-Kainourgio-Paravola), a large part of Xiromero (Katouna- Archontochori-Fyties), the municipality and the villages of Amfilochia (Sparto-Chalkiopoulo) and of course its city with all its suburbs. It is one of the largest employment promotion center in Greece both in area and in population. From a geographical point of view, it is an area with minimal access to the sea and with a population that deals mainly with the provision of servicesand secondarily with the primary sector. The participation of the tourism sector is minimal. Thetourism industry is underdeveloped in the region of Agrinio due to geographical peculiarity. A section of the workforce migrates during the summer months to other prefectures to ensure work or has settled permanently in other areas inside and outside Greece. Agrinio and in general Ailoakarnania is one of the most degraded areas of the country. Indeed, a predominantly rural area with people working in the agricultural sector, Aitoloakarnania was hit by the abolition or reduction of cultivation and production. With the internal migration in recent years and the policies followed mainly by the absence of central planning and the abandonment of the primary sector (tobacco) and all activities similar (processing) such as tobacco processing plants (e.g. PapastratouPanagopoulou) that they also gave income in the winter. In addition, the closure of the "Katsikis" pottery company with hundreds of employees, the shutdown of many local garment processing and manufacturing industries, the tendency to flee rural life, have led a rich and productive prefecture to obscurity in the last 50 years. Even the difficulty of road access and transportation worked in addition to other adverse factors.

\section{Reasons and Consequences of Unemployment}

The reasons why unemployment created are the following ones:

$\checkmark$ The use of new technologies.

$\checkmark$ Massive Production.

$\checkmark$ Fewer hands do the work for many.

$\checkmark$ The inability to increase demand due to economic recession.

$\checkmark$ Lower incomes and reduced consumption.

$\checkmark$ Disappearance of profession-specialties.

$\checkmark$ Urbanism and reduction-abandonment of primary sector.

$\checkmark$ Business go abroad (e.g. Bulgaria, etc.) due to lower employer costs and lower tax rate. 


\section{International Journal of Social Science and Economic Research}

$\checkmark$ Implemented economic and monetary policy (memoranda). Insufficient funding or lack of funds.

$\checkmark$ Explosive growth of the world population.

$\checkmark$ Wrong or non-existent professional orientation.

$\checkmark$ Small business investment in research and development.

$\checkmark \quad$ Investments with quick and immediate profits such as the stock market are preferred.

$\checkmark$ Wave of uncontrolled migration from poor to developed countries.

The non-response and non-adaptation of the educational community to modern needs. There is no strong link between the university and market demands.

The consequences of unemployment are the following ones:

$\checkmark$ Economic dependence.

$\checkmark$ Poor quality of life and survival issue.

$\checkmark$ Marginalization and inability to express its capabilities and abilities as well as underdevelopment and cultivation of these characteristics.

$\checkmark$ Increasing social and economic inequalities.

$\checkmark$ Expanding the gap between different classes.

$\checkmark$ Sharpening of discrimination and social disintegration. The unemployed are considered and end up citizens of category $B$.

$\checkmark$ Demagogy and escalation of nationalism and xenophobia.

\section{Methodology}

The purpose of this research is to study the phenomenon of unemployment in Greece, Western Greece and particularly in Agrinio. This study intends to identify the reasons of unemploymentand to suggest measures to tackle unemployment. At first, data were obtained from the Integrated Information System of the Greek Manpower Employment Organization and the Greek Statistical Authority. The survey took place from $15^{\text {th }}$ September 2019 to $15^{\text {th }}$ November2019. The 


\section{International Journal of Social Science and Economic Research}

ISSN: $2455-8834$

Volume:06, Issue:06 "June 2021"

sample of the data are the unemployed from 1979 to 2018 in Agrinio, Greece and Western Greece. These data are then grouped together and compiled in tables according to several factors such as gender, duration of unemployment, seasonality, etc. We compare the subsidized unemployment in Greece, Western Greece and Agrinio. Data analysis was done withthe help of the SPSS statistical analysis software. Moreover, hypothesis tests in various categories of unemployed take place using scientific methods provided by SPSS. The results are presented, analyzed, interpreted and evaluated. Finally, solutions and measures related to the plague of unemployment are proposed.

\section{Findings 1}

This section shed light in unemployment of the broader region of Agrinio at the threshold of the twenty first century according to specific parameters like age, sex and educational level. Moreover, comparing the unemployment over the years, its progress over time is intelligible. Firstly, examined the unemployment by sex, age and educational level between men and women in Agrinio the years of the crisis of Greek economy. Next, it is studied the average unemployment in Greece the years before crisis. Moreover, it is examined the registered and subsidized unemployed in Greece and Western Greece during the years of crisis. Finally, we examine the number of common and seasonal subsidized unemployed in Agrinio nowadays.

A seasonal unemployed person defined as a person who is employed only a few months per year. Moreover, subsidised unemployed are the unemployed that work seasonally and the coming months they receive unemployment benefits. Some cases of seasonal and subsidized unemployed are:

$\checkmark$ Employed in food professions and in tourist areas, such as waiters, cook, washers, barman etc.

$\checkmark$ Employees in tourism professions and tourism business such as airport guards, shopkeepers, car rental workers, tour officers and general shops that close at the end of the tourist season.

$\checkmark \quad$ Water guards in water companies.

$\checkmark$ Emergency personnel of firefighters and rangers.

$\checkmark$ Olive processing and standardization companies.

Common unemployed defined the persons whose work takes place throughout the year becausethe business that occupy work non-stop all the year (builder, painter etc.). Some cases of seasonal 
International Journal of Social Science and Economic Research

ISSN: 2455-8834

Volume:06, Issue:06 "June 2021"

and subsidized unemployed are:

$\checkmark$ Teachers of all levels (teachers, professors, nurses etc. of public or private sector)

$\checkmark$ Cleaners

$\checkmark$ Office workers and salespeople employed in companies that operate continuously the whole year.

Table 1 compares the unemployment between men and women according to their age from 2010 to 2011. We compare the data from 2010 to 2011 to examine the process of unemployment in the beginning of the crisis of Greek economy. Data analysis shows that unemployment in Agrinio affects more the youth and less the elder. Moreover, unemployed women are more than unemployed men. Finally, unemployment increased from 2010 to 2011.

Table 1: Unemployment by sex and age in the wider region of Agrinio in 2010 and 2011

\begin{tabular}{|c|c|c|c|c|c|c|}
\hline \multirow{2}{*}{ Age } & \multicolumn{3}{|c|}{$\mathbf{2 0 1 0}$} & \multicolumn{3}{c|}{$\mathbf{2 0 1 1}$} \\
\hline & Men & Women & Total & Men & Women & Total \\
\hline $\mathbf{1 5 - 2 9}$ & 18.9 & 27.5 & $\mathbf{2 2 . 8}$ & 28.6 & 38.3 & $\mathbf{3 2 . 9}$ \\
\hline $\mathbf{3 0 - 4 4}$ & 8.1 & 14.7 & $\mathbf{1 0 . 9}$ & 12 & 18.8 & $\mathbf{1 4 . 9}$ \\
\hline $\mathbf{4 5 - 6 4}$ & 6.5 & 9 & $\mathbf{7 . 5}$ & 9.2 & 11.4 & $\mathbf{1 0 . 1}$ \\
\hline $\mathbf{6 5 +}$ & 1.2 & 1.2 & $\mathbf{1 . 2}$ & 1 & 3.3 & $\mathbf{1 . 8}$ \\
\hline Total & $\mathbf{9 . 4}$ & $\mathbf{1 5 . 3}$ & $\mathbf{1 1 . 8}$ & $\mathbf{1 3 . 7}$ & $\mathbf{2 0}$ & $\mathbf{1 6 . 3}$ \\
\hline
\end{tabular}

Table 2 compares the unemployment between men and women from 2010 to 2011 according to their educational level. We can observe that unemployment in Agrinio affect more the loweducated persons. We can conclude that, education contributes to reduction of unemployment. Moreover, we can observe that unemployed women in Agrinio are more than unemployed men. Finally, unemployment in Agrinio increased from 2010 to 2011.

Table 2: Unemployment and educational level in in the wider region of Agrinio in 2010 and 2011

\begin{tabular}{|c|c|c|c|c|c|c|}
\hline \multirow{2}{*}{$\begin{array}{l}\text { Educational } \\
\text { Level }\end{array}$} & \multicolumn{3}{|c|}{$\mathbf{2 0 1 0}$} & \multicolumn{2}{|c|}{$\mathbf{2 0 1 1}$} & Total \\
\cline { 2 - 7 } & Men & Women & Total & Men & Women & \\
\hline IIliterate & 20.9 & 17 & $\mathbf{1 9 . 7}$ & 33.9 & 35.2 & $\mathbf{3 4 . 5}$ \\
\hline Few classes & 13.5 & 14.9 & $\mathbf{1 4}$ & 23 & 27.5 & $\mathbf{2 4 . 9}$ \\
\hline Primary School & 9 & 13.1 & $\mathbf{1 0 . 5}$ & 14.2 & 16.1 & $\mathbf{1 4 . 9}$ \\
\hline Secondary School & 12.3 & 16.3 & $\mathbf{1 3 . 6}$ & 16 & 21.6 & $\mathbf{1 7 . 8}$ \\
\hline Lyceum & 9.4 & 17.8 & $\mathbf{1 2 . 8}$ & 14.5 & 22.4 & $\mathbf{1 7 . 7}$ \\
\hline
\end{tabular}


International Journal of Social Science and Economic Research

ISSN: $2455-8834$

Volume:06, Issue:06 "June 2021"

\begin{tabular}{|c|c|c|c|c|c|c|}
\hline $\begin{array}{c}\text { Technological } \\
\text { Educational } \\
\text { Institute }\end{array}$ & 10 & 18.7 & $\mathbf{1 4 . 1}$ & 14 & 24.5 & $\mathbf{1 9}$ \\
\hline University & 6.2 & 9.9 & $\mathbf{8 . 1}$ & 8.4 & 14.6 & $\mathbf{1 1 . 6}$ \\
\hline Master-Phd & 5.8 & 9.4 & $\mathbf{7 . 4}$ & 9.3 & 10.3 & $\mathbf{9 . 7}$ \\
\hline Total & $\mathbf{9 . 4}$ & $\mathbf{1 5 . 3}$ & $\mathbf{1 1 . 8}$ & $\mathbf{1 3 . 7}$ & $\mathbf{2 0}$ & $\mathbf{1 6 . 3}$ \\
\hline
\end{tabular}

This section shows how unemployment in Greece change every five years. We examine the period from 1980 to the first decade of the twenty first century, namely the period before economic crisis. Table 3 presents the percentage of unemployment every five years from 1977 to 2009. We observe that unemployment in Greece has increased from 1977 to 1999 and decreased slightly from 2000 to 2009 . The unemployment from 1977 to 1989 is low and increased from 1990 to 2009.

Table 3: Average unemployment rate over periods of five years in Greece from 1977 to 2009

\begin{tabular}{|c|c|c|c|c|c|c|c|}
\hline Year & $\mathbf{1 9 7 7 - 7 9}$ & $\mathbf{1 9 8 0 - 8 4}$ & $\mathbf{1 9 8 5 - 8 9}$ & $\mathbf{1 9 9 0 - 9 4}$ & $\mathbf{1 9 9 5 - 9 9}$ & $\mathbf{2 0 0 0 - 0 4}$ & $\mathbf{2 0 0 5 - 0 9}$ \\
\hline Percent & $1.92 \%$ & $5.73 \%$ & $7.54 \%$ & $8.62 \%$ & $10.91 \%$ & $10.18 \%$ & $8.63 \%$ \\
\hline
\end{tabular}

In current section we study the development of unemployment in Greece during the Greek economic crisis. Table 4 depicts the evolution of the average unemployment from 2010 to 2017. As shown, unemployment in Greece has increased from 2010 to 2015 because of the economic crisis of 2009. On the other hand, unemployment in Greece decreased slightly from 2014 to 2017.

Table 4: Average unemployment rate in Greece from 2010 to 2017

\begin{tabular}{|c|c|c|c|c|c|c|c|c|}
\hline Year & $\mathbf{2 0 1 0}$ & $\mathbf{2 0 1 1}$ & $\mathbf{2 0 1 2}$ & $\mathbf{2 0 1 3}$ & $\mathbf{2 0 1 4}$ & $\mathbf{2 0 1 5}$ & $\mathbf{2 0 1 6}$ & $\mathbf{2 0 1 7}$ \\
\hline Percent & 12.73 & 17.89 & 24.53 & 27.48 & 26.59 & 24.96 & 23.55 & 21.59 \\
\hline
\end{tabular}

Table 5 illustrates the progress of subsidized unemployed in Greece and Western Greece from 2010 to 2018. It indicates that subsidized unemployed in Greece reaches its maximum point at 2010. This is explained because at the beginning of the crisis there are collective redundancies and citizens can't find stable work. From 2010 to 2014 subsidised unemployed has decreased. Furthermore, there is an increase from 2015 to 2018. Moreover, in Western Greece subsidized unemployed has decreased from 2010 to 2014, while there is an increase from 2015 to 2018. Unemployment rates in Greece and Western Greece maximized in 2010 and 2011 while they minimized in 2014. 
International Journal of Social Science and Economic Research

ISSN: $2455-8834$

Volume:06, Issue:06 "June 2021"

Table 5: Percentage of subsidized unemployed in Greece and Western Greece from 2010 to 2018

\begin{tabular}{|c|c|c|c|c|c|c|c|c|c|}
\hline Year & $\mathbf{2 0 1 0}$ & $\mathbf{2 0 1 1}$ & $\mathbf{2 0 1 2}$ & $\mathbf{2 0 1 3}$ & $\mathbf{2 0 1 4}$ & $\mathbf{2 0 1 5}$ & $\mathbf{2 0 1 6}$ & $\mathbf{2 0 1 7}$ & $\mathbf{2 0 1 8}$ \\
\hline Greece & 30.30 & 29.19 & 24.11 & 16.19 & 11.61 & 12.03 & 12.47 & 12.81 & 16.45 \\
\hline $\begin{array}{c}\text { Western } \\
\text { Greece }\end{array}$ & 21.72 & 22.56 & 17.96 & 11.20 & 7.60 & 8.12 & 9.21 & 9.40 & 11.09 \\
\hline
\end{tabular}

Table 6 presents the percentage of registered and subsidized unemployment in Greece from 2010 to 2018. Data present that registered and subsidized unemployed in Greece have increased from 2010 to 2013 while we observe a decrease from 2014 to 2017.

Table 6: Percentage of registered and subsidized unemployment in Greece from 2010 to 2017

\begin{tabular}{|c|c|c|c|c|c|c|c|c|}
\hline Year & $\mathbf{2 0 1 0}$ & $\mathbf{2 0 1 1}$ & $\mathbf{2 0 1 2}$ & $\mathbf{2 0 1 3}$ & $\mathbf{2 0 1 4}$ & $\mathbf{2 0 1 5}$ & $\mathbf{2 0 1 6}$ & $\mathbf{2 0 1 7}$ \\
\hline Registered & 12.73 & 17.89 & 24.53 & 27.48 & 26.59 & 24.96 & 23.55 & 21.59 \\
\hline Subsidized & 38.57 & 52.22 & 59.14 & 44.49 & 30.87 & 30.02 & 29.37 & 27.66 \\
\hline
\end{tabular}

Table 7 analyses the number of subsidised unemployed in Agrinio per month from 2016 to 2017. Results show that the number of seasonal subsidised unemployed in Agrinio reduced during the summer and increased during the winter. This happens because a large part of labourforce are employed in tourism industry during the summer period. In December the number of subsidized unemployed in Agrinio culminate. In this section it is worth mentioning to refer to the contribution of tourism to employment and gross domestic product in Greece. Tourism is the heavy industry of Greece. Twenty percent of the population is engaged in tourism professions which contribute to employment and gross domestic product. It's further growth may contribute to reducing unemployment. A further expansion to other forms of tourism couldbe the way out of the crisis. We need rational development of the possibilities that the location and the beauties of our country offer. Particularly, extension of the tourist season, projection of our history and shift to quality tourism. From 1975 to 2010 there is an evolution in unemployment. Unemployment has been on the rise since 1950. When Greece joined the economic monetary union, there was a decline in unemployment. However, it turned out that the country's economy did not have a good foundation. The abandonment of the primary sector and processing has led the country to crisis. An unavoidable crisis as the country's developmentrelied on loans. On the other hand, the corrupt 
International Journal of Social Science and Economic Research

ISSN: 2455-8834

Volume:06, Issue:06 "June 2021"

political leadership and the customer system could not resist and the worst was inevitable.

Table 7: Number of subsidised unemployed in Agrinio per month from 2016 to 2017

\begin{tabular}{|c|c|c|c|c|c|c|}
\hline \multirow{2}{*}{ Month } & \multicolumn{3}{|c|}{$\mathbf{2 0 1 6}$} & \multicolumn{2}{c|}{2017} \\
\cline { 2 - 7 } January & Common & Seasonal & Total & Common & Seasonal & Total \\
\hline February & 807 & 197 & 1004 & 641 & 219 & 860 \\
\hline March & 731 & 113 & 844 & 947 & 103 & 1050 \\
\hline April & 1110 & 51 & 1161 & 908 & 76 & 984 \\
\hline May & 737 & 14 & 751 & 781 & 22 & 803 \\
\hline June & 713 & 5 & 718 & 853 & 7 & 860 \\
\hline July & 1387 & 7 & 1394 & 1136 & 7 & 1143 \\
\hline August & 1490 & 16 & 1506 & 1338 & 5 & 1343 \\
\hline September & 1593 & 17 & 1610 & 1602 & 11 & 1613 \\
\hline October & 1151 & 26 & 1177 & 1127 & 22 & 1149 \\
\hline November & 996 & 89 & 1085 & 963 & 125 & 1088 \\
\hline December & 1040 & 281 & 1321 & 1122 & 399 & 1521 \\
\hline Average & $\mathbf{1 0 5 4}$ & $\mathbf{8 1}$ & $\mathbf{1 1 3 5}$ & $\mathbf{1 0 2 4}$ & $\mathbf{9 9}$ & $\mathbf{1 1 2 3}$ \\
\hline
\end{tabular}

\section{Findings 2}

In this section some interesting questions are raised and statistically examined (in 5\% confidence interval).

Table 8 investigates the trend of unemployment in Greece in recent years of 2015, 2016 and 2017. The null hypothesis is that there is statistically significant difference among years 2015 , 2016 and 2017 for the total unemployment in Greece. The results from the chi-square test show that the unemployment between years 2015, 2016 and 2017 differ and there is a statistically significant decrease of unemployment in Greece.

Table 8: Unemployment rates in Greece from 2015-2017

\begin{tabular}{|c|c|c|c|}
\hline Percentage of Unemployment in Greece & $\mathbf{2 0 1 5}$ & $\mathbf{2 0 1 6}$ & $\mathbf{2 0 1 7}$ \\
\hline Average & 24.96 & 23.55 & 21.59 \\
\hline
\end{tabular}

$\mathrm{H}_{0}$ : There is not statistically significant difference in total unemployment among years 2015, 2016 and 2017 in Greece. 
$\mathrm{H}_{1}$ : There is statistically significant difference in total unemployment among years 2015,2016 and2017 in Greece.

Asymp. Sig: $0.000<0.05 \mathrm{H}_{0}$ : Rejected

Chi-Square: 30.574

Table 9 presents the number of registered unemployed in Greece in recent years of 2016 and 2017. The null hypothesis is that there is not statistically significant difference between years 2016 and 2017 for the number of registered unemployed in Greece. The results from the chisquare test show that the number of registered unemployed in Greece is the same between years 2016 and 2017.

Table 9: Number of registered unemployed in Greece in 2016 and 2017

\begin{tabular}{|c|c|c|}
\hline Registered Unemployed people in Greece & $\mathbf{2 0 1 6}$ & $\mathbf{2 0 1 7}$ \\
\hline Number & 1010025 & 987295 \\
\hline
\end{tabular}

H0: There is not statistically significant difference between years 2016 and 2017 for thenumber of registered unemployed people in Greece.

H1: There is statistically significant difference between years 2016 and 2017 for the number of registered unemployed people in Greece.

Asymp. Sig: $0.299>0.05$ H0: Accepted

Chi-Square: 1.080

Table 10 deals with the measure of long-term and the long-term unemployment in three regions (Greece, Western Greece and Agrinio) the last year. The null hypothesis is that there is not statistically significant difference between long-term registered rates among Greece, Western Greece and Agrinio. The results from the chi-square tests show that there is statistically significant difference among the three regions, with stronger long-term unemployment in Agrinio, less in Western Greece and even less in Greece.

Table 10: Single registered unemployed in 2017 and 2018

\begin{tabular}{|c|c|c|c|c|c|c|c|c|c|}
\hline & \multicolumn{3}{|c|}{ Greece } & \multicolumn{3}{c|}{ Western Greece } & \multicolumn{3}{c|}{ Agrinio } \\
\cline { 2 - 9 } & $\begin{array}{c}\text { Long- } \\
\text { Term }\end{array}$ & $\begin{array}{c}\text { Short- } \\
\text { Term }\end{array}$ & Total & $\begin{array}{c}\text { Long- } \\
\text { Term }\end{array}$ & $\begin{array}{c}\text { Short- } \\
\text { Term }\end{array}$ & Total & $\begin{array}{c}\text { Long- } \\
\text { Term }\end{array}$ & $\begin{array}{c}\text { Short- } \\
\text { Term }\end{array}$ & Total \\
\hline Average & 54.15 & 45.85 & 100 & 61.56 & 38.44 & 100 & 65.76 & 34.24 & 100 \\
\hline
\end{tabular}


$\mathrm{H}_{0}$ : There is not statistically significant difference between long-term registered rates among Greece, Western Greece and Agrinio.

$\mathrm{H}_{1}$ : There is statistically significant difference between long-term and short-term registered rates among Greece, Western Greece and Agrinio.

Asymp. Sig: $0.00<0.05 \mathrm{H}_{0}$ : Rejected

Chi-square: 28.352

Table 11 studies the male and female unemployment rates among Greece, Western Greece and Agrinio during the last year. The null hypothesis is that there is not statistically significant difference between the male unemployment rates among these three regions. The results from the chi-square tests show that there are statistically significant differences between the male unemployment rates among the three regions. Unemployed men are more in Agrinio, less in Western Greece and even less in Greece. Moreover, we can see that unemployed women are more than men in all regions.

Table 11: Percentage of unemployed to the total number of registered unemployed in 2017 and 2018

\begin{tabular}{|c|c|c|c|c|c|c|c|c|c|}
\hline & \multicolumn{3}{|c|}{ Greece } & \multicolumn{3}{c|}{ Western Greece } & \multicolumn{3}{c|}{ Agrinio } \\
\cline { 2 - 10 } & Men & Women & Total & Men & Women & Total & Men & Women & Total \\
\hline Average & 39.84 & 61.16 & 100 & 42.99 & 57.01 & 100 & 37.06 & 62.94 & 100 \\
\hline
\end{tabular}

$\mathrm{H}_{0}$ : There is not statistically significant difference between the male unemployment rates among the three regions.

$\mathrm{H}_{1}$ : There is statistically significant difference between the male unemployment rates among the three regions.

Asymp. Sig: $0.00<0.05 \mathrm{H}_{0}$ : Rejected

Chi-square: 35.002

Table 12 deals with the number of subsidized and registered unemployed in Greece, Western Greece and Agrinio during the last year. The null hypothesis is that there is not statistically difference in the percentage of subsidized and registered unemployed among the three areas. The results from the chi-square tests show that there is statistically significant difference in percentages of subsidized unemployed and registered unemployed in Greece, Western Greece and Agrinio. Such percentages are higher in Greece, less in Western Greece and even less in Agrinio. 
International Journal of Social Science and Economic Research

ISSN: 2455-8834

Volume:06, Issue:06 "June 2021"

Table 12: Number and percentage of subsidized/registered unemployed in 2017 and 2018

\begin{tabular}{|c|c|c|c|c|c|c|}
\hline $\begin{array}{c}\text { Subsidized/Registered } \\
\text { Unemployed }\end{array}$ & \multicolumn{2}{|c|}{ Greece } & \multicolumn{2}{c|}{ Western Greece } & \multicolumn{2}{c|}{ Agrinio } \\
\cline { 2 - 7 } & Subsidized & Registered & Subsidized & Registered & Subsidized & Registered \\
\hline Number & 132231 & 985155 & 7107 & 71457 & 1146 & 13844 \\
\hline Average & \multicolumn{2}{|c|}{13.26} & \multicolumn{2}{|c|}{9.9} & & \multicolumn{2}{c|}{} \\
\hline
\end{tabular}

H0: There is not statistically significant difference in the percentage of subsidized andregistered unemployed among the three areas.

H1: There is statistically significant difference in the percentage of subsidized and registered unemployed among the three areas.

Asymp. Sig. $0.00<0.05$ H0: Rejected

Chi-square: 16.125

Table 13 is occupied with the comparison of seasonal unemployment and especially with the percentages of seasonal subsidized and total subsidized in Greece, Western Greece and Agrinio during the last year. The null hypothesis is that there is not statistically significant difference between the percentages of subsidized seasonal and total subsidized in Greece, Western Greece and Agrinio. The results from the chi-square tests show that there is not statistically significant difference between the percentages of subsidized seasonal and total subsidized in Greece, Western Greece and Agrinio.

Table 13: Percentage of unemployed to the total number of registered unemployed in 2017 and 2018

\begin{tabular}{|c|c|c|c|c|c|c|c|c|c|}
\hline Subsidized & \multicolumn{3}{|c|}{ Greece } & \multicolumn{3}{c|}{ Western Greece } & \multicolumn{3}{c|}{ Agrinio } \\
\cline { 2 - 10 } Unemployed & Common & Seasonal & Total & Common & Seasonal & Total & Common & Seasonal & Total \\
\hline Average & 0.7416 & 0.2584 & 100 & 0.7978 & 0.2022 & 100 & 0.91 & 0.09 & 100 \\
\hline
\end{tabular}

$\mathrm{H}_{0}$ : There is not statistically significant difference between the percentages of subsidizedseasonal and total subsidized in Greece, Western Greece and Agrinio.

$\mathrm{H}_{1}$ : There is statistically significant difference between the percentages of subsidizedseasonal and total subsidized in Greece, Western Greece and Agrinio.

Asymp. Sig. $0.417>0.05 \mathrm{H}_{0}$ : Accepted

Chi-square: 7.105 
Table 14 is occupied with the percentages of subsidized men in Agrinio, Western Greece and Greece during the last year. The null hypothesis is that there is not statistically significant difference for percentages of subsidized men among Greece, Western Greece and Agrinio in period 2017-18. The results from the chi-square tests show that there is a statistically significant difference in Greece, Western Greece and Agrinio. The percentage of subsidized men in Agrinio is higher, less in Western Greece and even less in Greece.

Table 14: Percentage of subsidized men and women in Greece, Western Greece and Agrinio from 2017 to 2018

\begin{tabular}{|c|c|c|c|c|c|c|c|c|c|}
\hline Subsidized & \multicolumn{4}{|c|}{ Greece } & \multicolumn{3}{c|}{ Western Greece } & \multicolumn{3}{c|}{ Agrinio } \\
\cline { 2 - 11 } Unemployed & Men & Women & Total & Men & Women & Total & Men & Women & Total \\
\hline Number & 59698 & 72533 & 132231 & 3739 & 3368 & 7107 & 679 & 467 & 1146 \\
\hline Average & 45.2 & 54.8 & 100 & 52.5 & 47.5 & 100 & 59.9 & 40.1 & 100 \\
\hline
\end{tabular}

$\mathrm{H}_{0}$ : There is not statistically significant difference for percentages of subsidized men among Greece, Western Greece and Agrinio in period 2017-2018.

$\mathrm{H}_{1}$ : There is statistically significant difference for percentages of subsidized men among Greece, Western Greece and Agrinio in period 2017-2018.

Asymp. Sig. $0.000<0.05 \mathrm{H}_{0}$ : Rejected

Chi-square: 21.694

Table 15 presents the number of subsidized men and women in Agrinio during the last year. The null hypothesis is that there is not statistically significant difference for the average number of subsidized between men and women in Agrinio. The results from the chi-square tests show that there is a statistically significant difference between the average number of subsidized men and women in Agrinio. Totally, the proportion of subsidized men is higher than that of women.

Table 15: Number of subsidized men and women in Agrinio in 2017 and 2018

\begin{tabular}{|c|c|c|c|}
\hline \multirow{2}{*}{$\begin{array}{c}\text { Average Number of } \\
\text { Subsidized for 2017-2018 }\end{array}$} & \multicolumn{3}{|c|}{ Agrinio } \\
\cline { 2 - 4 } & Men & Women & Total \\
\cline { 2 - 4 } & 679 & 467 & 1146 \\
\hline
\end{tabular}

H0: There is not statistically significant difference for the average number of subsidizedbetween men and women in Agrinio.

$\mathrm{H} 1$ : There is statistically significant difference for the average number of subsidized between men and women in Agrinio.

Asymp. Sig. $0.001<0.05$ H0: Rejected 
Chi-square: 3.658

Table 16 deals with the comparison of the average number of subsidized common and seasonal unemployed people in Agrinio in 2017. The null hypothesis is that there is not statistically significant difference between the average number of common and seasonal unemployed people in Agrinio in 2017. The results from the chi-square tests show that there is a statistically significant difference between the average number of common and seasonal unemployed people in Agrinio in 2017.

Table 16: Number of common and seasonal subsidized in Agrinio in 2017

\begin{tabular}{|c|c|c|c|}
\hline Average Number of & \multicolumn{3}{|c|}{ Agrinio } \\
\cline { 2 - 4 } Subsidized for year & Common & Seasonal & Total \\
\cline { 2 - 4 } 2017 & 1031 & 115 & 1146 \\
\hline
\end{tabular}

H0: There is not statistically significant difference between the average number of common and seasonal unemployed people in Agrinio for year 2017.

H1: There is statistically significant difference between the average number of common and seasonal unemployed people in Agrinio for year 2017.

Asymp. Sig. $0.000<0.05$ H0: Rejected

Chi-square: 78.000

Table 17 presents the comparison of the average number of common and seasonal subsidized unemployed people between years 2016 and 2017 in Agrinio. The null hypothesis is that thereis not statistically significant difference between the average number of subsidized unemployed people in Agrinio between years 2016 and 2017. The results from the chi-square tests show that there is not statistically significant difference for the average number of subsidized unemployed people between years 2016 and 2017 in Agrinio. The percentage of subsidized unemployed people in Agrinio is statistically the same for years 2016 and 2017.

Table 17: Number of common and seasonal subsidized unemployed in Agrinio for years 2016-17

\begin{tabular}{|c|c|c|c|c|c|c|}
\hline \multirow{3}{*}{$\begin{array}{c}\text { Average } \\
\text { Number of } \\
\text { Subsidized } \\
\text { Unemploved }\end{array}$} & \multicolumn{3}{|c|}{ Agrinio 2016} & \multicolumn{3}{|c|}{ Agrinio 2017} \\
\hline & Common & Seasonal & Total & Common & Seasonal & Total \\
\hline & 1054 & 81 & 1135 & 1024 & 99 & 1123 \\
\hline
\end{tabular}

$\mathrm{H}_{0}$ : There is not statistically significant difference between the average number of subsidized 
unemployed people in Agrinio between years 2016 and 2017.

$\mathrm{H}_{1}$ : There is statistically significant difference between the average number of subsidized unemployed people in Agrinio between years 2016 and 2017.

Asymp. Sig. $0.696>0.05 \mathrm{H}_{0}$ : Accepted

Chi-square: 18.250

Table 18 refers to the comparison of the average number of subsidized seasonal unemployed in Agrinio between years 2016 and 2017. The null hypothesis is that there is not statistically significant difference for the average number of subsidized seasonal unemployed people in Agrinio between years 2016 and 2017. The results from the chi-square tests show that there is not statistically significant difference for subsidized seasonal unemployed between years 2016 and 2017. So, the number of seasonal subsidized unemployed is statistically the same for years 2016 and 2017.

Table 18: Number of common and seasonal subsidized in Agrinio for years 2016-17

\begin{tabular}{|c|c|c|c|c|c|c|}
\hline Average & \multicolumn{3}{|c|}{ Agrinio 2016 } & \multicolumn{3}{c|}{ Agrinio 2017 } \\
\cline { 2 - 7 } $\begin{array}{c}\text { Number of } \\
\text { Subsidized }\end{array}$ & Common & Seasonal & Total & Common & Seasonal & Total \\
\cline { 2 - 7 } & 1054 & 81 & 1135 & 1024 & 99 & 1123 \\
\hline
\end{tabular}

H0: There is not statistically significant difference for the average number of subsidized seasonal unemployed people in Agrinio between years 2016 and 2017.

$\mathrm{H} 1$ : There is statistically significant difference for the average number of subsidized seasonal unemployed people in Agrinio between years 2016 and 2017.

Asymp. Sig. $0.112>0.05$ H0: Accepted

Chi-square: 10.291

Table 19 presents the number of seasonal subsidized unemployed men and women in Agrinio in 2017-18 and shed light in the relationship between seasonality and gender. The null hypothesis is that there is not statistically significant difference between seasonality and gender. The results from the chi-square tests show that there is not statistically significant there is not statistically significant difference between seasonality and gender. Moreover, seasonality is not statistically affected by the gender. 
International Journal of Social Science and Economic Research

ISSN: $2455-8834$

Volume:06, Issue:06 "June 2021"

Table 19: Number of average common and seasonal subsidized in Agrinio in 2017-18

\begin{tabular}{|c|c|c|c|}
\hline Number of & \multicolumn{3}{|c|}{ Agrinio } \\
\cline { 2 - 4 } Subsidized & Common & Seasonal & Total \\
\hline Men & 605 & 74 & 679 \\
\hline Women & 432 & 41 & 473 \\
\hline Average & 1037 & 115 & 1152 \\
\hline
\end{tabular}

$\mathrm{H}_{0}$ : There is not statistically significant difference between seasonality and gender. $\mathrm{H}_{1}$ : There is statistically significant difference between seasonality and gender.

Asymp. Sig. $0.096>0.05 \mathrm{H}_{0}$ : Accepted

Chi-square: 43.372

\section{Conclusions}

In this section the conclusions drawn by the statistical analysis are discussed, while some interesting ideas for future work are proposed. The percentage of unemployment in European Union is close to 7\%. In the south, the unemployment rate is much higher. In Greece, percentage of unemployment is $20.7 \%$. In recent years, a small recovery has begun, but the percentage remains high and is affecting individuals, families and businesses and creating problems in thefunctioning of the state. Generally, youth unemployment is higher. Unemployment among woman is higher than men and higher in people with lower qualifications. Finally, the average unemployment rate in Greece has increased from 2010 to 2014 because of the economic crisis of 2009. On the other hand, subsidized unemployed in Greece reach the maximum point at the beginning of the crisis because of staff redundancies. In years 2015, 2016 and 2017, even though there is a decline in the unemployment rate in Greece, the number of unemployed in years 2016 and 2017 is the same. Seasonal subsidized are equal than common subsidized in Greece. The number of seasonal subsidized unemployed in Agrinio is reduced in summer (because most of them are employed in tourism enterprises) and increased in winter. Seasonal subsidized are fewer than common subsidized in Agrinio. Furthermore, subsidized men are more than women in Agrinio. In addition, the share of common subsidized persons is higher than that of seasonal ones in Agrinio. Last but not least, the number of subsidized and seasonal subsidized is the same for the years 2016 and 2017 in Agrinio. There is no statistically significant difference between subsidized unemployment in Greece with that in the region of Agrinio. Moreover, long term unemployment is higher in Agrinio, less in Western Greece and even less in Greece from 2017 to 2018. The percentage of subsidized men in Agrinio is higher, less in Western Greece and even less in Greece. 


\section{Proposals}

We sepatare the proposals to government and business proposals. In order the unemployment to be reduced, the following proposals that government should imply are suggested:

$\checkmark$ Enhance the primary sector and enforce processing of agricultural and livestock products

$\checkmark$ Abolition of partisanship and unworthiness

$\checkmark$ Fighting corruption

$\checkmark$ Employee evaluation

$\checkmark$ Unemployment subsidy should be abolished and given both as a part of employee's salary and employment subsidy by the Greek Manpower Employment Organisation (GMEO) andthe employer

$\checkmark$ Relationship between the GMEO, businesses and unemployed should become more reliable

$\checkmark$ GMEO should be responsible for the right combination between the skills the unemployed have and the jobs where they can work.

$\checkmark$ Financial incentives should be given to people who desire to set up their own businesses, such as subsidies and tax exemptions.

$\checkmark$ Increase government spending and investment in public works.

$\checkmark$ Investment in renewable energy sources

$\checkmark$ Reduce lending rates to businesses

$\checkmark$ Easy access to capital and lending by investors

$\checkmark$ Tax reduction

We also propose some measures that businesses should impose to tackle unemployment:

$\checkmark$ Increase in demand

$\checkmark$ Vocational training and retraining measures 


\section{International Journal of Social Science and Economic Research}

$\checkmark$ Lifelong learning

$\checkmark$ Investment in innovation

$\checkmark$ Interconnection of universities with local market

$\checkmark$ Use of new technologies

$\checkmark$ Investment in research and development by businesses

\section{References}

Barslund M., Gros D. (2017), "Declining Youth Unemployment in Europe: The Effect of the Business Cycle or the European Youth Guarantee?," CESifo Forum, Ifo Institute - Leibniz Institute for Economic Research at the University of Munich, vol. 18, No. 2, pp. 39-46

Caliendo M., Schmidl R. (2015), Youth Unemployment and Active Labor Market Policies in Europe, Journal of Labor Policy, Vol. 5 No. 1, pp. 1-30

Dietrich H. (2013), Youth unemployment in the period 2001-2010 and the European crisis looking at the empirical evidence, Institute for Employment Research, Vol.19, No. 3, pp. 305-324

Hammarström A., Janlert U., Theorell T. (1988), Youth unemployment and ill health: Results from a 2-year follow-up study, Social Science \& Medicine, Vol. 26, No. 10, pp. 1025-1033

Lawler K., Katsouli E., Pallis D. (2003), The Impact of the agricultural sector on cyclical unemployment and output in EU, Agricultural Economics Review, Vol. 4, No. 1, pp. 1-12

Mroz T., Savage T. (2006), The long-term effects of youth unemployment, The Journal of Human Resources, Vol. 41, No. 2, pp. 259-293

Mukoyama T., Şahin A. (2009), Why did the average duration of unemployment become so much longer? Journal of Monetary Economics, Vol. 56, No. 2, pp. 200-209

O'Higgins, Niall. (1997), The Challenge of Youth Unemployment. International Social Security Review, Vol. 50, No. 4, pp. 63-93

Putun M., Karatas A.S., Akyildiz I.E. (2017), The economic consequences of the youth unemployment case in EU Countries: A critical analysis, International Journal of Economics and Finance Studies, Vol. 9, No. 1, pp. 1309-8055 
International Journal of Social Science and Economic Research

ISSN: $2455-8834$

Volume:06, Issue:06 "June 2021"

Rawls J. (2005), Justice as Fairness, Book of theory of justice, Part. 1, Chapter. 1, pp. 3-4

Shimer R. (1999), "Why is the U.S. Unemployment Rate So Much Lower? NBER Macroeconomics Annual 1998, vol. 13, No. 2, pp. 11-74

Stephen R., Jones, W., Craig R. (2006), Unemployment and Nonemployment: Heterogeneitiesin Labor Market States, Review of Economics and Statistics, Vol. 88, No. 2, pp. 314-323

Taylor Jim \& Bradley Steve. (1997), "Unemployment in Europe: A Comparative Analysis of Regional Disparities in Germany, Italy and the UK," Kyklos, Wiley Blackwell, vol. 50, No. 2,pp. $221-245$

Tsakalotos E. (1998), The assessment: Demographic economic policies the pasok experiment in Greece oxford review of economic policy, Oxford review of economic policy, Vol: 14, No: 1, pp:1-18

Zeilstra A.S., Elhorst J.P. (2014), "Integrated Analysis of Regional and National Unemployment Differentials in the European Union", Taylor \& Francis Journals, vol. 48, No. 10, pp. 1739-17 